\title{
Infrastructure Enhancement and Households' Economic Activities: Lesson From Indonesia
}

\author{
Dwi Wulandari ${ }^{1}$, Bagus Shandy Narmaditya ${ }^{1}$, Putra Hilmi Prayitno ${ }^{1} \&$ Suryati Ishak $^{2}$ \\ ${ }^{1}$ Faculty of Economics, Universitas Negeri Malang, Indonesia \\ ${ }^{2}$ Faculty of Economics and Management, Universiti Putra Malaysia, Malaysia \\ Correspondence: Dwi Wulandari, Faculty of Economics, Universitas Negeri Malang, Jalan Semarang 5 Malang 65145, \\ Indonesia. E-mail: dwi.wulandari.fe@um.ac.id
}

Received: September 16, 2019

Accepted: November 5, 2019

Online Published: December 15, 2019

doi:10.5430/rwe.v10n3p315

URL: https://doi.org/10.5430/rwe.v10n3p315

\begin{abstract}
This study aims at examining the impact of infrastructure advancement of Southern Cross Lane (JLS) in Malang, Indonesia toward households' economic activities. Furthermore, this study intended to understand the presence of new road infrastructure and tourism sectors toward households' economic activities. This research applied a descriptive study by conducting focus group discussions with stakeholders and the local community in Malang, Indonesia. In addition, semi-structured questionnaires were implemented to obtain a better understanding of the existing phenomenon. The findings of the study showed that in the short term, the presence of a new road in Southern Cross Lane changes the economic activities of the household while in the long term, it provides various opportunities to be developed such as tourism sectors, hotels, and restaurants. However, the development efforts from each region depend on the plan of the local community. Furthermore, the existence of a new road in Southern Cross Lane contributes to greater access between cities in the south of East Java in Indonesia.
\end{abstract}

Keywords: infrastructure enhancement, household activities, local economic development

\section{Introduction}

The development of economy in a country is intended to enhance equality and human welfare. For these matters, it needs an obvious appropriate approach to reach greater growth followed by equality. In addition, the development of economic promotes better job opportunity, economic growth and economic welfare (Sipahutar, 2016; Sutikno et al., 2017). Infrastructure enhancement plays a pivotal role primarily to accelerate the process of national or regional development. Sumadiasa et al. (2016) remarked that infrastructure advancement leads to better economic growth in a region or country. In other words, either economic growth or investment both nationally and regionally cannot be separated from the presence of infrastructures such as transportation, road, communication and so forth (Ansar et al., 2016).

The study on economic development theory explained that an attempt to create and increase economic activities an adequate infrastructure is needed (Srinivasu \& Rao, 2013; Gurara et al., 2018). This is reasonable because infrastructure is the main support for the implementation of a regional development process (Ghosh \& De, 1998). The nature and type of infrastructure needed by a region are influenced by natural characteristics and patterns of population distribution that are typical of the area. Infrastructure is not only needed to increase competitiveness in order to encourage more investment, production and trade activities but also to accelerate equitable development that leads to poverty alleviation and unemployment can be reduced.

The inequality of distribution of road infrastructure is a classical problem In Indonesia that needs to be addressed immediately. The insufficient quality of roads in the number of areas empirically is mainly due to structural constraints, namely the prioritization of the region because it is considered not to have a direct impact on the increase regional income or not yet optimal support for the related sector. This is undeniable because the development problems in the regions began with the absence of adequate road infrastructure. In Indonesia, the infrastructure budget continues to increase from IDR 155 trillion in 2014 to around IDR 410 trillion in 2018 (Ministry of Finance, 2018). From the allocation of public and private financing, infrastructure is seen as a locomotive for national and regional development. 
The Southern Cross Line was originally included in the Provincial strategy program as an effort to balance the inequality of the northern and southern regions in East Java, but the subsequent development of the infrastructure development became a National Strategy program into the development of the South Coast Road in East Java Province is a road and asset infrastructure development that supports economic movements in East Java which can trigger East Java's economic growth in the Southern Region, which has been dominated by the Northern region. The Southern Cross Line has a length of $634.11 \mathrm{~km}$ passing eight regions passed including Pacitan, Trenggalek, Tulungagung, Blitar, Malang, Lumajang, Jember, Banyuwangi, from the coast Pacitan Beach reaches Banyuwangi.

The presence of road infrastructure will support the productivity of other economic sectors that will lead to economic growth and improve the socio-cultural conditions of people's lives through multiple effects. While directly related to the construction sector, road infrastructure will also create employment and business opportunities. Therefore, the existence of good road infrastructure will be able to encourage the creation of stability in various aspects of society to support the program of national development. With the increasing need for infrastructure development to support economic growth, the Indonesian government has provided a better framework for attracting investment and private participation at a scale that is measurable in infrastructure projects.

Previous studies on infrastructure enhancement have conducted in several areas in Indonesia and other countries. Riley-Powell et al. (2018) remarked that the road construction plays an important influence on improving the quality of life and human well-being. In addition, Asher \& Novosad (2019) mentioned that rural roads increase the value of consumption, increasing labor productivity and access to employment, as well as increasing real prosperity. In Indonesia context, Prapti et al. (2015) conducted a study on the impact of road construction in Semarang, Central Java. The findings showed that the existence of new road promotes the growth of enterprises. The prior studies are more likely focused on the impact of road construction and its impact on the impact on quality life, in this study researchers would like to engage to the several aspects such as economic, tourism, and social sciences aspect by the establishment of Southern Cross Lane (JLS) in Malang, East Java.

\section{Method}

This research applied a qualitative approach. In this method, the researchers intended to provide comprehensively about the presence of Southern Cross Lane (JLS) in Malang, East Java and its impact on various aspects particularly on household economic activities, potential tourism sector and so forth. This research was conducted throughout Southern Cross Lane (JLS) in Malang, Indonesia considering several important issues and representations to the study. In addition, the data were divided into two namely primary and secondary data. The primary data was gathered directly in the field through several ways such as providing questionnaires, engaging in-depth interviews with semi structured-interviews, and conducting a focus group discussion. The questionnaires are related to public perception about the establishment of Southern Cross Lane (JLS) in Malang and their economic activities, and the advantages and drawbacks of the Southern Cross Lane (JLS) in Malang. Whereas, the secondary data was obtained from Statistics Indonesia and other relevant resources such as Malangkab.bps.go.id. Furthermore, the data were analyzed accordingly using Miles \& Huberman's (1984) model following several steps namely the process of data collection, data reduction, data display, and verification.

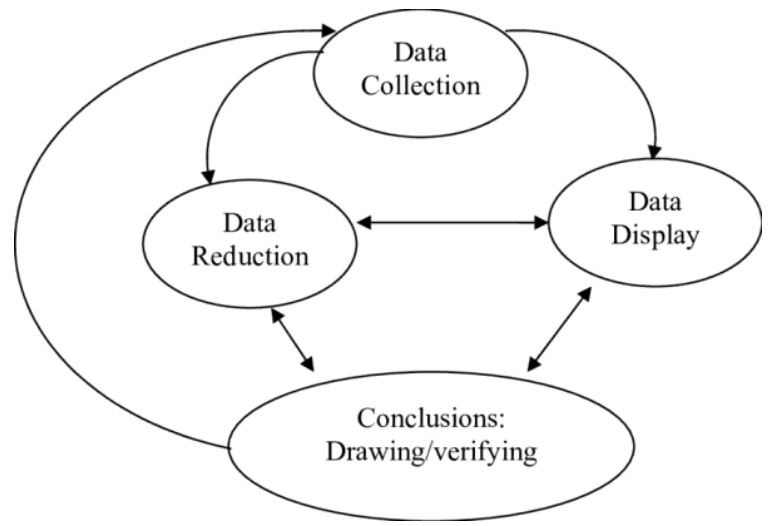

Figure 1. Analysis Data Model by Miles \& Huberman (1984)

Figure 1 explains the analysis model following steps including data collection, data reduction, data display, and 
verification. The data reducing includes summarizing, choosing the main things, focusing on the important things, looking for themes and patterns and removing unnecessary. The data that must be reduced will provide a clear and easy picture for the researcher to do the next data, and look for it if necessary. In addition, data display matters because social phenomena are complex, and dynamic so that what is found when moving in the field and after a long completion in the field will improve data development. Lastly, the conclusion from the qualitative research that is expected is new findings that have never before existed. Findings can be in the form of a description or description of an object that was previously unclear, so that after being discussed it becomes clear.

\section{Results and Discussion}

\subsection{Road Infrastructures and Household's Economic Activities}

Socio-economic movement is a process of changing the system in society including changes in the economic activities in the community. It has led to changes in several aspects such as livelihoods, income, the standard of living and so forth. Furthermore, the presence of the road infrastructure of the Southern Cross Lane in Malang also has a consequence on economic aspects. It can be seen from the changes in household economic behavior. In more detail, previously, based on interviews with respondents, most people around southeast cross lane in Malang have a livelihood as fishermen. They also mentioned that if he did not go to sea, usually they would look for side jobs such as looking for grass for animal feed. Regarding the income earned, they mentioned that the income received certainly would not depend on the results of arrest, if not at sea would not get income. Income received can be per day, per week, or per month, this depends on whether fishing or not. In addition, the community around JLS also had several communities that worked as farmers and farm laborers. They also said that the income received by the community was also uncertain. However, they believe that the existence of the Southern Cross lane in Malang seems like the opportunity to be developed rather than a challenge.

The movement of economic activities in this area was initiated by critical thinking from the community to provide a better chance since the road was established. They forced their creativity to promote local potential to be enhanced for their prosperity. These findings are in line with Hartoto et al. (2017) remarked that the presence of new road has successfully increased the traders' willingness to think creatively to provide innovative products. Indeed, the local community in Malang regency attempted to provides several possibilities businesses such as providing merchant stores, culinary businesses, coffee shops, and so forth. This is evidenced by increasing the number of small enterprises throughout Southern Cross Lane in Malang.

From the findings, it also can be found that the economic activities of the household experienced a better trend. Formerly, for many housewives that only stay at home with single income from their husbands, at present, they participate in economic activities by providing some business including handicrafts. They have a women community to provide things by their creativities such as keychain, clothing, culinary and so forth. In order to support women's business, the government takes role in assisting him and providing a workshop for the community. Therefore, it can be concluded that the presence of a new road in Malang regency provides an opportunity to be an entrepreneur and enhance household wellbeing. Indeed, the previous study by Asher \& Novosad (2019) mentioned that road construction promotes a better community welfare.

The construction of the Southern Cross Lane in Malang also plays an important role in increasing labor productivity, access to new jobs, increasing the value of consumption and increasing prosperity for the local community. Roads as a form of infrastructure development have a major influence on increasing population mobility, accelerating the rate of distribution that drives the development of a region, stimulates the emergence of other developments such as public infrastructure. The development aims to improve household welfare.

\subsection{The Presence of Southern Cross Lane and Tourism Sector in Malang}

The Southern Cross Lane Malang is linked with the tourism sites in Malang such as Balekambang beach, Sendang Biru beach, and several other beaches. Southern Cross Lane in Malang is an area that is very much related to the livelihood of many people live along the area. The enhancement of road along Southern Cross Lane Malang provides better access to the tourism sector. It used to the local community to earn their income by making stalls at the points targeted by visitors. Residents around Southern Cross Lane in Malang have various types of potential from agricultural products such as corn, bananas, green beans, peanuts, sweet potatoes, soybeans, papaya and so forth.

The existence of Southern Cross Lane in Malang has a multiplier effect on other sectors such as agriculture, handicraft industry, clothing industry, various service sectors, and so forth. The potential of Southern Cross Lane in Malang should be read as an opportunity to carry out development in various aspects of life for the welfare of people's lives, one of which is through the development of Southern Cross Lane in Malang as a tourism object. 
Besides, since the infrastructure development in Southern Cross Lane in Malang existed, it promotes several new beaches that potentially increase income for both regional income and household.

There are several fascinating places such as Bajulmati Beach, Goa Cina Beach, Ngantep Beach, Ngudel Beach, Ungapan Beach, Batu Bengkung Beach, Batu Leter Beach, Tiga Warna Beach, and Teluk Asmara Beach. It implies that the development of road infrastructures successfully affect tourism sectors in the area. Based on the Focus Group discussion that has been conducted previously, they mentioned that at the time there are approximately 32 beaches throughout Southern Cross Lane in Malang. Moreover, tourism sectors have the main function for regional income. It also has roles in supporting economic growth, social and culture, environment conservations and so forth.

\subsection{The Government Role in Enhancing Household Wellbeing}

Both the Local and Regional Government take a strategic role in supporting the household welfare and the growth of economic. Economic growth is an indicator of seeking out the current development progress to determine the sustainability of development. Based on the focus group discussion that has been conducted, it can be known that the infrastructure needed in a region is affected by several natural characteristics and the pattern of population distribution that is typical in the area. The road infrastructure is not only needed to increase the competitiveness level but it also enhances the other economic activities such as investment, production, and trade. Additionally, this matter aimed to reduce income inequality which will lead to a decline the level of poverty and unemployment rate. Besides, the existence of the road infrastructure is highly important in supporting the human development process in a region.

The role of government in acquaintance with southern-cross lane and household welfare is seen from three main functions namely as coordinator, facilitator, and stimulator. First, as a coordinator, the government provides relevant strategies for developing area. In addition, it also plans the development area which primarily boosting economic growth in its relation with tourism sector. The role of government can be seen from the development planning of the Southern-Cross Lane and development area in Malang. This program is intended to boost the economic activities and growth in Southern area of East Java Province that have various potential resources that have not optimally developed.

The role of government as a facilitator can be seen from providing facilities in supporting the tourism sector. In addition, the government also focuses on enhancing the natural resources and environmental purposes. Lastly, as a stimulator, the government's role is aimed at enlarging investment. The government thinks that the development of economic in the area needs financial support. For instance in several tourism sectors throughout Southern-cross lane have a great opportunity to be developed. However, in fact there is less attention for the investor to invest their money in the area.

\section{Conclusion}

The study aims at understanding the socio-economic impact on the establishment of a new road in Southern Cross Lane (JLS) in Malang. The presence of a new road in Southern Cross Lane (JLS) changes economic activities of household while in the long term, it provides various opportunity to be developed such as tourism sectors, hotels, and restaurants. However, the development efforts from each region depend on the plan of the local community. Furthermore, the existence of new road in the Southern Cross Lane (JLS) contributes to greater access between cities in southern In Indonesia. Lastly, the role of government in enhancing household welfare can be seen from several functions namely as a coordinator, facilitator, and stimulator.

\section{Acknowledgements}

This research was funded through a grant by the Directorate of Research and Community Services (LPPM) Universitas Negeri Malang.

\section{References}

Ansar, A., Flyvbjerg, B., Budzier, A., \& Lunn, D. (2016). Does infrastructure investment lead to economic growth or economic fragility? Evidence from China. Oxford Review of Economic Policy, 32(3), 360-390.

Ghosh, B., \& De, P. (1998). Role of Infrastructure in Regional Development: A Study Over the Plan Period. Economic and Political Weekly, 3039-3048.

Gurara, D., Klyuev, V., Mwase, N., \& Presbitero, A. F. (2018). Trends and Challenges in Infrastructure Investment in Developing Countries. International Development Policy. Revue internationale de politique de développement, 10(10.1).

Hartoto, W. E., Rinawati, T., Meiriyanti, R., \& Puspitasari, D. (2017). Dampak Perkembangan Jalan Lingkar 
Ambarawa Terhadap Perkembangan UKM Serabi Ngampin Ambarawa. Jurnal Dinamika Sosial Budaya, 19(1), $1-10$.

Prapti, L., Suryawardana, E., \& Triyani, D. (2015). Analisis dampak pembangunan infrastruktur jalan terhadap pertumbuhan usaha ekonomi rakyat di Kota Semarang. Jurnal Dinamika Sosial Budaya, 17(1), 82-103.

Riley-Powell, A., Lee, G., Naik, N., Jensen, K., O’Neal, C., Salmón-Mulanovich, G., ... Paz-Soldan, V. (2018). The impact of road construction on subjective well-being in communities in Madre de Dios, Peru. International Journal of Environmental Research and Public Health, 15(6), 1271.

Sipahutar, M. A. (2016). Effects of credit on economic growth, unemployment and poverty. Jurnal Ekonomi Pembangunan: Kajian Masalah Ekonomi dan Pembangunan, 17(1), 37-49.

Srinivasu, B., \& Rao, P. S. (2013). Infrastructure Development and Economic Growth: Prospects and Perspective. Journal of Business Management and Social Sciences Research, 2(1), 81-91.

Sumadiasa, I. K., Tisnawati, N. M., \& Wirathi, I. G. A. P. (2016). Analisis Pengaruh Pembangunan Infrastruktur Jalan, Listrik dan PMA terhadap Pertumbuhan PDRB Provinsi Bali Tahun 1993-2014. E-Jurnal Ekonomi Pembangunan Universitas Udayana, 5(7), 925-947.

Sutikno, S., \& Suliswanto, M. S. W. (2017). The Impact of Industrialization on the Regional Economic Development and Community Welfare. Signifikan: Jurnal Ilmu Ekonomi, 6(2), 231-246. 